\title{
KOMUNIKASI ORGANISASI SEKOLAH Studi Kasus : UPT SMP 20 Mei Kota Depok
}

\author{
Muhammad Shindy \\ Program Studi Desain Komunikasi Visual \\ Fakultas Bahasa dan Seni, Universitas Indraprasta PGRI \\ Jl. Nangka No. 58 C Tanjung Barat Jagakarsa, Jakarta Selatan \\ Shindy88.ms@gmail.com
}

\begin{abstract}
Abstrak
Penelitian ini membahas tentang komunikasi organisasi. Komunikasi adalah salah satu hal yang menentukan keberhasilan, efektifitas dan ketahanan organisasi. Tujuan dari penelitian ini adalah untuk menyarankan manajemen sekolah yang baik terutama untuk komunikasi organisasi yang membuat kinerja sekolah menjadi lebih baik. Pemimpin dan semua pengusaha diharapkan melakukan komunikasi terbuka, dan penuh dengan keadilan. Selain itu, yang tidak kalah pentingnya dalam sebuah organisasi, komunikasi organisasi dan iklim komunikasi juga penting, yaitu melakukan komunikasi yang baik. Metode penelitian yang digunakan adalah studi kasus kualitatif. Instrumen yang digunakan adalah wawancara mendalam. Observasi dan studi dokumentasi. Wawancara dilakukan oleh informan kunci yang merupakan kepala sekolah dan juga didukung oleh informan kunci yang terdiri dari guru dan office boy
\end{abstract}

Kata Kunci : komunikasi, organisasi, sekolah

\begin{abstract}
This Research is about the organizational communication. Communication is one of the factor that determine the successful, effectivity and enduring of the organizational.The objective of this research is to suggest good college school management especially for organizational communication which good communication makes better school performance. The leader and all the employes are expected to do open communication, full of honest and fairness Besides that last but not least in an organization, organizational communication climate and effectiveness communication is also important, which by doing good communication the culture of working organization become better. The method of this study used is qualitative case study. The instrument used is the depth interview. Observation and documentation study. The interviews were conducted with key informant which was the head school and also supported by the key informant that consisting of theachers and office boy
\end{abstract}

Keyword : communication, organication, school 


\section{PENDAHULUAN}

Komunikasi adalah prasyarat kehidupan manusia. Kehidupan manusia akan tampak hampa atau tiada kehidupan sama sekali apabila tidak ada komunikasi, karena tanpa komunikasi antar manusia, baik secara perorangan, kelompok ataupun organisasi tidak mungkin dapat terjadi. Manusia membutuhkan dan senantiasa membuka serta menjalin komunikasi atau berhubungan dengan sesamanya, selain itu pada sejumlah kehidupan dalam diri manusia yang hanya dapat dipuaskan lewat berkomunikasi, oleh karena itu penting bagi kita menjadi terampil dalam berkomunikasi. Dengan berkomunikasi, manusia dapat saling berhubungan, berinteraksi dan bekerja sama antar satu sama lain, baik dalam kehidupan seharihari, ditempat pekerjaan ataupun dimana saja manusia berada. Tidak ada manusia yang tidak pernah terlibat dalam komunikasi. Komunikasi memelihara motivasi dengan memberikan penjelasan kepada para pegawai tentang apa yang harus dilakukan, seberapa baik mereka mengerjakannya dan apa yang dapat dilakukan untuk meningkatkan kinerja jika sedang berada di bawah standar.

Dalam suatu sekolah komunikasi sangat diperlukan, dengan adanya komunikasi yang baik, keadaan sekolah dapat berjalan lancar dan berhasil. Dalam kehidupan pun para anggota sekolah tidak mungkin hidup terisolasi, baik dari rekan-rekan kerjanya maupun lingkungannya, strategi yang akan dilakukan, tujuan yang hendak dicapai serta program kerja yang hendak dilaksanakan, kesemuanya perlu dikomunikasikan secara baik antar satu individu dengan individu atau kelompok yang lain.

Sebut saja didalam suatu sekolah pastilah ada program-program sekolah yang terdiri dari kegiatan-kegiatan yang akan dilaksanakan oleh para anggota sekolah untuk kemajuan sekolah tersebut mencakup program jangka pendek, jangka menegah, panjang. Dalam merumuskan dan pelaksanaan program sekolah tersebut, tentunya kepala sekolah tidak bekerja sendiri melainkan dibantu oleh beberapa orang guru dan Koordinator bidang kurikulum dan guru lain yang bersangkutan. Pada saat merumuskan program sekolah tersebut, pastilah antara kepala sekolah, guru ataupun Koordinator melakukan komunikasi baik itu bersifat formal ataupun informal, dalam bentuk formal misalnya kepala sekolah mengadakan rapat atau pertemuan sederhana, sedangkan bentuk informal terwujud dengan komunikasi pada saat senggang atau istirahat, sehingga suasana lebih mencair dan menghindari ketegangan. Sekolah seperti hal lembaga lainnya merupakan suatu organisasi, yaitu unit terkoordinasi yang setidaknya terdiri dari dua orang dan berfungsi mencapai sasaran tertentu atau serangkai sasaran. Dikatakan suatu organisasi karena di dalamnya terdapat berbagai macam bagian yang memiliki tugas dan fungsi masing-masing namun memiliki satu tujuan bersama. Untuk mengelola sebuah sekolah, diperlukan kemampuan manajemen yang baik agar arah kegiatan sesuai dengan visi dan misi yang di inginkan.

Sebagai sebuah unit organisasi, sekolah juga di pandang sebagai pusat informasi yang memiliki struktur organisasi tersendiri dengan fungsi masing-masing. Dalam struktur itu sendiri terdapat hubungan hierarkis, antara atasan dan bawahan, begitu juga sebaliknya antara bawahan dengan sesama bawahan. Dalam menjalankan tugas terdapat garis komando komunikasi, garis intruksi dan garis koordinasi. Dengan adanya komunikasi dalam organisasi diharapkan mampu 
memberikan pencerahan dan kemudahan dalam mengelola sebuah organisasi, saling memahami, saling percaya, saling hormat, saling berbagi dan lain sebagainya merupakan perekat bagi anggota dalam menjalankan tugas pokok dan fungsinya terhadap pencapaian tujuan pribadi maupun tujuan organisasi.

Pada sekolah terdapat unit-unit pendukung dalam menjalankan peran serta fungsinya sebagai lembaga pendidikan untuk mencapai visi dan misinya. Salah satu unit tersebut adalah Unit Pelaksana Teknis (UPT) sekolah.

Tujuan secara umum penelitian ini adalah untuk mengetahui bagaimana Proses Komunikasi Organisasi, mengetahui bagaimana Efektivitas komunikasi organisasi, dan mengetahui bagaimana Iklim Komunikasi Organisasi di SMP 20 MEI Kota Depok.

Dipilihnya komunikasi organisasi sebagai objek penelitian ini karena bagaimanapun lengkapnya sarana dan prasarana yang dimiliki suatu organisasi, apabila tidak ditunjang oleh pengelolaan yang baik dalam hal ini komunikasi yang baik, maka akan sulit bagi suatu organisasi untuk dapat mencapai suatu tujuan. Sebab diasumsikan jika komunikasi organisasi sudah baik, maka akan dapat menjalankan tugas pokok dan fungsi orang-orang di dalam organisasi dengan baik pula, apabila komunikasi organisasi telah terbentuk dengan baik maka dengan sendirinya organisasi akan dapat dibentuk sesuai dengan yang diinginkan.

\section{TINJAUAN PUSTAKA}

\section{Proses Komunikasi}

Arni Muhammad (2001:4) telah mendefinisikan komunikasi, yaitu "pertukaran pesan verbal maupun nonverbal antara si pengirim dengan si penerima pesan untuk mengubah tingkah laku". Miftah toha, Katz dan Khan
(1998:167) juga menyampaikan bahwa "komunikasi adalah suatu proses peyampaian dan penerimaan berita atau informasi dari seseorang ke orang lain. William J.Seiller dan Melissa L.Beall (2008:3) mendefinisikan, "communication as the simultaneous sharing and creating of meaning through human symbolic interaction". Komunikasi sebagai berbagi simultan dan penciptaan makna melalui interaksi simbolik manusia. Larry A.Samovar dan Jack Mils (1976:4) menyatakan "communication is the process of sharing with another person, or persons one's knowledge, interest, attitude, opinion, feelings, and ideas" Komunikasi adalah proses berbagi dengan orang lain atau orang seseorang pengetahuan, minat, sikap, pendapat, perasaan, dan ide-ide. Angelo Kinicki dan Brian K.Williams menyampaikan (2003:513) "communication is the transfer of information and understanding from one person to another". Komunikasi adalah transfer informasi dan pengertian dari satu orang ke orang lain.

Berdasarkan pendapat beberapa ahli di atas, dapat didefinisikan Komunikasi sebagai proses penyampaian informasi antara dua orang atau lebih yang juga meliputi penukaran informasi antara atasan manusia dan mesin.

\section{Efektivitas Komunikasi}

Bambang Harjimanto (1999:36) efektivitas berasal dari kata efek yang dalam kamus besar bahasa Indonesia berarti "Akibat, pengaruh atau dapat membawa hasil". Suatu keadaan yang menuntut seseorang melakukan suatu perbuatan dengan maksud tertentu yang memang dikehendaki maka orang itu dikatakan efektif kalau menimbulkan akibat atau mempunyai maksud sebagaimana yang dikehendakinya. Selain itu menurut Komaruddin (1979: 37) pengertian efektivitas adalah "suatu 
keadaan yang menunjukkan tingkat keberhasilan kegiatan manajemen dalam mencapai tujuan yang ditetapkan terlebih dahulu" Komunikasi yang efektif memerlukan persepsi, ketepatan, kredibilitas, pengendalian dan keserasian.

Courtland L Bovee dan John V Thill (2003:45). yang diterjemahkan oleh Alexander Sindoro dalam buku Komunikasi Bisnis, jilid 1 menyampaikan pedoman efektif untuk mengatasi hambatan dan memperbaiki keterampilan komunikasi, yaitu, (1) memelihara iklim komunikasi terbuka, (2) bertekad memegang teguh etika berkomunikasi, (3) memamahami kesulitan dalam komunikasi antara budaya, (4) menggunakan pendekatan komunikasi yang berpusat pada penerima, (5) menggunakan teknologi secara bijaksana dan bertanggung jawab untuk memperoleh dan berbagi informasi, (6) menciptakan dan memproses pesan secara efektif dan efisien

Jadi dari pengertian di atas dapat dikatakan bahwa efektivitas adalah keberhasilan kegiatan manajemen dalam mencapai tujuan yang telah ditetapkan lebih dahulu, dimulai dari merencanakan, mengorganisasikan, melaksanakan, mengawasi sampai pada mengevaluasi apabila ada beberapa tindakan yang tidak terlaksana, sehingga efek yang ditimbulkan dari kegaiatan tersebut dapat sesuai dengan yang diinginkan

\section{Iklim Komunikasi}

Iklim komunikasi sebuah organisasi mempengaruhi cara hidup kita, kepada siapa kita berbicara, siapa yang kita sukai, bagaimana perasaan kita, bagaimana kegiatan kerja kita, dan bagaimana cara kita menyesuaikan diri dengan organisasi. Arni Muhammad (2002:84) dalam bukunya mengatakan Iklim komunikasi yang penuh persaudaraan mendorong para anggota organisasi berkomunikasi secara terbuka, rileks, ramah tamah dengan anggota yang lain. sedangkan iklim negatif menjadikan anggota tidak berani berkomunikasi secara terbuka dan penuh persaudaraan

Redding (1972) dalam buku Komunikasi Organisasi karangan R. Wayne Pace dan Don F.Faules yang dietrjemahkan oleh deddy Mulyana (2010:148) menyatakan bahwa iklim komunikasi organisasi jauh lebih penting dari pada keterampilan atau teknik-teknik komunikasi semata-mata dalam menciptakan suatu organisasi yang efektik

Goldhaber,

(http://amarsuteja.blogspot.com/2012/02 /iklim-komunikasi-organisasi.html diakses:5 Febuari 2014) mengemukakan lima dimensi penting dari iklim komunikasi tersebut.

"Supportiveness", atau bawahan mengamati bahwa hubungan komunikasi mereka dengan atasan membantu mereka membangun dan menjaga perasaan diri berharga dan penting, (2) Partisipasi membuat keputusan, (3) Kepercayan, dapat dipercaya dan dapat menyimpan rahasia. Haney, menemukan bahwa makin tinggi kepercayaan cenderung motivasi kerja makin tinggi.

Keterbukaan dan keterusterangan, (5) Tujuan kinerja yang tinggi, pada tingkat mana tujuan dikomunikasikan dengan jelas kepada anggota organisasi

Iklim komuikasi organisasi terdiri dari persepsi-persepsi atas unsur-unsur organisasi dan pengaruh unsur-unsur tersebut terhadap komunikasi. Pengaruh ini didefinisikan, disepakati, dikembangkan dan dikokohkan secara berkesinambungan melalui dengan anggota organisasi lainya. Pengaruh ini menghasilkan pedoman bagi keputusankeputusan dan tindakan-tindakan individu, dan mempengaruhi pesan-pesan mengenai organisasi. 
Berdasarkan uraian di atas, iklim komunikasi organisasi sangatlah penting bagi sebuah lembaga atau organisasi, agar dapat menimbulkan rasa kesetiakawanan dan loyalitas antara atasan dengan bawahan maupun dengan sesama bawahan sehingga dapat meningkatkan kegairahan bekerja dan meningkatkan moral serta disiplin dalam bekerja

\section{METODE PENELITIAN}

Tujuan penelitian ini adalah melakukan studi kasus, terhadap (1) Proses komunikasi Organisasi, (2) Efektivitas komunikasi organisasi, (3) Iklim Komunikasi Organisasi di SMP 20 MEI Kota Depok

Penentuan informan dalam penelitian ini dilakukan secara puposive sampling (sampel bertujuan) yakni menentukan informan yang telah ditentukan kriterianya sehingga memudahkan peneliti menjelajahi objek yang diteliti.

Data yang diperoleh dianggap telah memadai jika telah sampai pada taraf redudancy (data telah jenuh, ditambah sample tidak lagi memberikan informasi yang baru). Artinya bahwa dengan menggunakan responden selanjutnya boleh dikatakan tidak lagi diperoleh tambahan informasi baru yang berarti.

\section{PEMBAHASAN}

\section{Proses Komunikasi}

Proses Komunikasi sebagai wahana untuk saling berhubungan dengan orang lain, tidak hanya sekedar melalui percakapan melaikan komunikasi dapat diwujudkan dalam bentuk pentransferan pesan, menyampaikan pikiran dan perasaan terhadap suatu hal hingga pada proses mempengaruhi orang lain.

Proses komunikasi yang terjalin di UPT SMP 20 MEI berjalan dengan apa adanya, karena sudah disibukkan dengan pekerjaan masing-masing, sehingga mereka yang tidak dapat menggunakan kesempatan, memanfaatkan waktu luang untuk menjalin komunikasi dengan baik kepada atasan maupun sesama rekan kerja, kecuali kalau dalam pertemuan rutin, baru kelihatan pembicaraannya agak serius sedangkan diluar pertemuan formal biasa saja,

Berdasarkan hasil analisis di atas dapat ditarik kesimpulan umum bahwa proses komunikasi yang terjalin di UPT SMP 20 MEI dengan para koordinator, guru, wali kelas, ketua jurusan maupun dengan staff TU sekolah SMP 20 Kota Depok tidak terpaku dengan rapat rutin mingguan, bulanan, tahunan di sekolah saja, namun terkadang kepala sekolah melakukannya dengan cara informal Hanya saja tidak semua para anggota organisasi dapat memanfaatkan waktu dan peluang untuk saling berkomunikasi, berbagi dan lain sebagainya.

\section{Efektivitas Komunikasi}

Efektivitas komunikasi disekolah menjadi salah satu langkah dan metode yang tepat bagi seluruh personil sekolah, baik itu kepala sekolah sebagai pemimpin organisasi beserta para staff dan para bawahannya dalam menjalin hubungan kerjasama dan koordinasi dalam rangka mencapai tujuan sekolah.

Berdasarkan hasil wawancara dan obeservasi dapat diinterpretasikan bahwa efektivitas komunikasi yang terjalin di UPT SMP 20 MEI yaitu kurang dapat berjalan secara efektif, salah satu penyebabnya adalah kurangnya pelestarian komunikasi secara dua arah sehingga personil sekolah kurang melakukan interaksi, kepala sekolah sebagai pimpinan hanya memberikan intruksi, menerima laporan-laporan pertanggung jawaban kinerja guru dan para staff, faktor lainnya yaitu komunikator yang kurang kompeten dan tidak memahami isi pesan yang akan disampaikan dengan 
jelas. Ketika terjadi komunikasi tidak efektif, maka yang timbul adalah kesepian, konflik, ketidakpuasan profesional, penderitaan. Dengan demikian, bahwa pengaruh komunikasi yang tidak efektif membawa stakeholder dalam organisasi kepada konflik. Baik konflik antara pimpinan dengan karyawan, antara karyawan itu sendiri. Jika konflik sudah muncul, maka cost akan banyak yang terbuang sia-sia. Masing-masing individu dalam organisasi saling curiga, tidak terbuka dan yang pasti tidak merasakan kenyamanan dan tidak ada kepuasan dalam berorganisasi. Tuntutan akan banyak, tetapi penyelesaian tuntutan pun tidak jelas. Hal ini akan mengakibatkan organisasi rugi atau bahkan bangkrut, dengan demikian tujuan organisasi tidak tercapai (gagal). Kebutuhan dasar tidak terpenuhi dengan baik, terjadi kesalahpahaman, ketidakjujuran dan prasangka buruk. Dari satu konflik dapat menyebabkan konflik lanjutan yang lebih serius, mempertajam masalah dan ini benar-benar membawa kerugian besar bagi organisasi.

Berdasarkan hasil analisis diatas dapat ditarik kesimpulan umum bahwa komunikasi tidak akan berjalan efektif apabila komunikator tidak dapat menyampaikan pesan sesuai dengan pengertian komunikan, yang pada akhirnya efek dari komunikasi tidak akan pernah sesuai dengan yang dikehendaki.

\section{Iklim Komunikasi}

Iklim komunikasi merupakan refleksi komunikasi yang terjadi pada level organisasi dan individu. Pada level organisasi, iklim komunikasi meliputi hal-hal pokok seperti bagaimana berkomunikasi dalam memotivasi dan merangsang para pegawai agar berusaha mencapai tujuan organisasi serta bagaimana membuat para pegawai mengidentifikasikan diri ke dalam organisasi. Pada level individu, iklim komunikasi berkaitan dengan perkiraan mengenai apakah sikap para pegawai dalam berkomunikasi sehat atau tidak di dalam suatu organisasi

Iklim komunikasi organisasi dibentuk melalui interaksi antara anggota-anggota organisasi. Iklim komunikasi organisasi merupakan suasana komunikasi yang tercipta oleh pola hubungan antar pribadi yang berlaku dalam organisasi.

Adanya komunikasi dalam suatu organisasi akan membentuk suatu iklim komunikasi. Iklim komunikasi organisasi ada yang bersifat positif dan negatif. Iklim komunikasi organisasi yang bersifat positif dapat mendorong produktivitas kerja karyawan dalam suatu organisasi, sehingga lebih mempermudah tercapainya tujuan organisasi. Sebaliknya iklim komunikasi oragnisasi yang negatif, dapat menghambat produktivitas tinggi karyawan dalam organisasi yang mengakibatkan organisasi berjalan menuju keujung tanduk kehancurannya

Berdasarkan hasil wawancara dan obeservasi dapat diinterpretasikan bahwa Iklim komunikasi yang terjalin di UPT SMP 20 MEI yang terbuka membuat para personil sekolah bebas melakukan apa saja, dalam artian bebas menyampaikan aspirasi apa saja tanpa dibatasi lalu bebas dengan siapa saja dan kapan saja

Berdasarkan analisis di atas dapat ditarik kesimpulan umum bahwa Iklim komunikasi di UPT SMP 20 MEI bersifat terbuka, kondusif dan nyaman untuk saling berinteraksi seluruh personil sekolah dan tidak lagi merasa sungkan, takut, atau segan saat berkomunikasi baik itu dengan pimpinan kepala sekolah, koordinatornya atau dengan sesama rekan kerja guru dan karyawan lainnya, karena dengan kondisi iklim komunikasi yang baik tidak ada lagi pembatas hubungan kinerja para pesonil sekolah, sehingga diharapkan dengan iklim komunikasi 
yang baik akan memudahkan kerjasama antar personil guru atau karyawan dan memberikan implikasi yang positif dalam berkomunikasi dengan siapa saja, mengomunikasikan apa saja dan kapan saja dalam mencapai visi dan misi sekolah

\section{PENUTUP}

Berdasarkan pembahasan tiga subfokus penelitian yang diajukan, yakni Proses Komunikasi, Efektivitas Komunikasi dan iklim Komunikasi. Maka penelitian ini dapat disimpulkan Proses komunikasi sebagai wahana untuk berhubungan dengan orang lain, tidak hanya sekedar melalui percakapan melainkan proses komunikasi dapat diwujudkan dalam bentuk pentransferan pesan, menyampaikan pikiran dan perasaan terhadap hal lain, hingga mempengaruhi orang lain.

Proses Komunikasi organisasi yang terjalin dikalangan internal pengelola sekolah yakni antara atasan dengan bawahan dan sesama rekan kerja berjalan dengan apa adanya dengan kata lain belum sepenuhnya berlangsung sebagaimana mestinya. Komunikasi yang tidak berjalan baik akan menimbulkan implikasi pada pengelolaan sekolah dalam mencapai visi dan misi organisasi ditempat mereka bekerja. Dengan adanya proses komunikasi yang baik dalam organisasi/perusahaan maka akan ada proses penyampaian informasi baik dari atasan kepada bawahan. Tetapi proses komunikasi tidak hanya menyampaikan informasi atau hanya agar orang lain juga bersedia menerima dan melakukan perbuatan atau kegiatan yang dikehendaki sehingga akan terjalin suasana yang harmonis kepada para bawahan mengetahui secara pasti keinginan atasan, dan apa yang harus dikerjakan kaitannya dengan usaha kerjasama untuk mencapaitujuan organisasi/perusahaan yang telah ditetapkan

Efektivitas komunikasi disekolah menjadi salah satu langkah dan metode yang tepat bagi seluruh personil sekolah, baik itu kepala sekolah sebagai pemimpin lembaga pendidikan beserta para guru dan staff dalam menjalin hubunga kerjasama dalam rangka pencapaian visi dan misi sekolah.

Permasalahan Efektivitas dalam komunikasi organisasi yang terjalin antara atasan dan bawahan pada UPT SMP 20 MEI adalah : kurangnya pemahaman pengelolaan sekolah terhadap komunikasi dalam organisasi secara keseluruhan, sehingga apa yang dikomunikasikan tidak efektif, dan tidak ada waktu untuk saling berbagi informasi baik dengan atasan maupun dengan sesama rekan kerja

Keadaan lingkungan suatu komunikasi dapat mempengaruhi hal-hal yang ada didalam organisasi tersebut, iklim yang menyenangkan dan kondusif membuat para personil didalamnya ikut merasa nyaman untuk melakukan kinerjanya. Karena pada dasarnya Iklim Komunikasi sangat menentukan hasil dari penyampaian pesan pada lawan bicaranya, keduanya memiliki kualitas yang tepat agar komunikasi menjadi baik dan memberikan implikasi yang positif diseluruh personil sekolah, ini terlihat dari Iklim Komunikasi yang terjadi di UPT SMP 20 MEI yaitu daintaranya saling memberi dukungan, Kepercayaan, kebebasan dalam berkomunikasi dengan siapa saja, mengkomunikasikan apa saja dan kapan saja

Berdasarkan kajian dan temuan penelitian, pada bagian ini peneliti memiliki rasa tangung jawab untuk memperbaiki dan mengembangkan sistem komunikasi organisasi sekolah SMP 20 MEI melalui rekomendasi.

Pertama, kepada seluruh Pimpinan baik itu Kepala Sekolah dan KAUR agar 
dapat berkomunikasi dengan baik, terbuka, terus terang, dan penuh kejujuran agar kegiatan dan seluruh program kerja dalam organisasi dapat berjalan dengan baik demi tercapainya visi dan misi sekolah

Kedua, kepada seluruh guru dan karyawan hendaklah selalu memperhatikan dan menjalin antara atasan dan bawahan dan sesama rekan kerja agar saling berbagi, menghormati dan menghargai karena kita semua adalah satu kesatuan dan mahluk sosial yang saling membutuhkan

Ketiga, untuk menjaga hubungan baik antara atasan dengan bawahan dan pembahasan persoalan kerja organisasi sebaiknya dicanangkan program pertemuan rutin bagi seluruh pengelola UPT Sekolah, yang pelaksanaannya bisa bulanan bahkan setiap semester karena hubungan antar karyawan yang dibangun berdasarkan iklim dan kepercayaan atau budaya organisasi yang positif turut memberi andil dalam menciptakan iklim komunikasi efektif. Rasa percaya, keyakinan, keterbukaan, dukungan keamanan, kepuasan, keterlibatan dan tingginya harapan merupakan cermin iklim komunikasi organisasi yang ideal.

Kemudian pimpinan hendaknya memperhatikan kebutuhan kemampuan guru dan karyawan yang masih sangat minim latar pendidikannya dari kependidikan baik dari kualitas dan kuantitasnya.

\section{DAFTAR PUSTAKA}

A.Samovar, L. \& Mils, J. (1976). Oral Communication. United State of
America:

Wm.C.Brown

Company Publishers,

Bovee, C.L. dan Thill, J.V. (2003). Komunikasi bisnis I. Jakarta: Indeks Kelompok Gramedia,

Harjimanto, B. (1999). Kamus Besar Bahasa Indonesia. Surabaya: CV. Bintang Tuntas,

J.Seiller, W., dan Beall, M.L. (2008). Communication Making Connections. United State Of America: Pearson Education,

Kinicki, A. dan Williams, B.K.. (2003). Management A Praticical Introduction. NewYork : McGraw-Hill,

Komaruddin. (1979).vEnsiklopedia Manajemen Bandung : Alunsi,

Muhammad, A. (2001). Komunikasi Organisasi. Jakarta: PT. Bumi Aksara, (2002). Komunikasi Organisasi. Jakarta : PT. Bumi Aksara,

Pace, R. W. P. dan Faules, D.F.. (2010). Komunikasi Organisasi. Bandung: PT Remaja Rosdakarya,

Toha, M. (1998). Perilaku Organisasi, konsep Dasar dan Aplikasinya. Jakarta: PT. Rajagrafindo Persada,

http://amarsuteja.blogspot.com/2012/02/i klim-komunikasi-organisasi.html diakses 5 Febuari 2014 